\title{
Analisis Penggunaan Nama-Nama Tuhan Agama Selain Islam Sebagai Rujukan kepada Allah
}

\author{
An Analysis of the Use of the Names of God in Religions Other than Islam \\ as Equivalence to Allah
}

\author{
MOHD ASYRAN SAFWAN KAMARUZAMAN*, MOHD HAIDHAR KAMARZAMAN \& \\ KAMARUDIN SALLEH ${ }^{1}$
}

\begin{abstract}
This study analyzes the use of the name of god other than Islam to Allah SWT. There are some issues that have been raised about the use of names for god in other religions to Allah SWT. While in the debate of the salaf and the Khalaf scholars, the names for Allah SWT are taken Tawqifiyyah based on the evidence in the Quran and Sunnah only. Besides the tawqifiyyah method, Allah SWT cannot be named by a name other than what He names for Himself in the Qur'an and the Sunnah. This study uses a qualitative method that includes data collection, content analysis, comparative analysis, and historical-based analysis. The findings show that there are some known Islamic figures who named Allah SWT as Brahma as Dr. Zakir Naik and allow the name of Allah SWT by a name taken from other religions such as Nazim al-Qubrusi. They named Allah SWT instead of Tawqifi as agreed by the scholars of the Ahli Sunnah Wal Jamaah. Their opinion is against the Ahli Sunnah Waljamaah Method.
\end{abstract}

Keywords: Zakir Naik, Nazim al-Qubrusi, Brahma, Name of Allah, Tawqifi

Umat Islam meyakini bahawa Allah SWT merupakan Pencipta bagi sekalian alam yang berhak disembah dengan sebenar-benarnya. Allah SWT yang disembah umat Islam adalah Esa tidak berbilang, bersifat dengan segala sifat kesempurnaan, yang mencipta makhluk-Nya dan Dia tidak menyerupai makhluk-Nya, Dia tidak berhajat kepada ruang, tempat, arah dan waktu. Allah SWT yang disembah umat Islam tidak bersifat dengan jisim sama ada jisim yang kasar seperti kayu, mahupun jisim yang lembut seperti cahaya. Bagaimanapun, berlainan dengan keyakinan umat Hindu yang meyakini bahawa sembahan mereka adalah berbilang-bilang dengan pelbagai jenis seperti Vishnu, Siva dan Brahma. Mereka meyakini sembahan mereka bertempat, berjisim, mempunyai anggota badan dan sebagainya. Keyakinan umat Hindu ini jelas tersasar dengan konsep Tauhid umat Islam.

Bermula daripada bapa manusia yang pertama iaitu Nabi Adam a.s sehingga kepada Nabi Muhammad s.a.w, keyakinan umat Islam tidak berubah. Semua Nabi-Nabi umat Islam menyeru ke arah mentauhidkan Allah dan menjauhi syirik. Apa yang membezakan di antara umat Islam pengikut Nabi Muhammad SAW dan pengikut Nabi-Nabi yang lain ialah syariat kehidupan

\footnotetext{
${ }^{1}$ Mohd Asyran Safwan Kamaruzaman*(corresponding author), doctoral student at Centre for Akidah and Global Peace, Faculty of Islamic Studies, Universiti Kebangsaan Malaysia, 43600 BANGI, Selangor, Malaysia, e-mail: masyran.yayasan.waqaf@gmail.com; Mohd Haidhar Kamarzaman Ph.D., lecturer at Centre for Akidah and Global Peace, Faculty of Islamic Studies, Universiti Kebangsaan Malaysia, 43600 BANGI, Salangor, Malaysia, email: haidhar@ukm.edu.my; Kamarudin Salleh, Ph.D., assoc. professor at Centre for Akidah and Global Peace, Faculty of Islamic Studies, Universiti Kebangsaan Malaysia, 43600 BANGI, Selangor, Malaysia, email: dins@ukm.edu.my.
} 
mereka sahaja. Ini sebagaimana dinyatakan oleh Syeikh Abdullah al-Harari (al-Harari 2004). Perkara ini dikuatkan dengan hadis daripada Nabi SAW sebagaimana yang diriwayatkan dalam Sahih Muslim Juzu' 4, Hadith No. 2365 (Muslim n.d.):

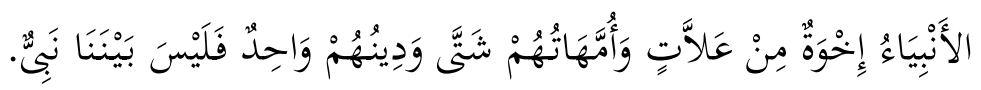

Para Nabi itu adalah saudara satu bapa, ibu-ibu mereka berbeza akan tetapi agama mereka satu. Dan Tidak ada di antara kami (Nabi Isa dan Nabi Muhammad) seorang Nabi.

Akidah ketuhanan umat Islam berteraskan kepada dasar Tauhid. Seorang tokoh sufi agung, Imam Junayd al-Baghdadi telah mentakrifkan Tauhid (al-Baghdadi n.d.) sebagai:

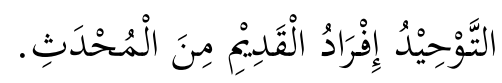

Tauhid ialah mensucikan Allah SWT yang bersifat sedia ada daripada menyerupai makhluk-Nya.

Sesuai dengan pentakrifan ringkas oleh Imam Junayd al-Baghdadi ini, maka dapatlah diketahui bahawa seorang yang beragama Islam mengimani akan keesaan Allah, sekaligus menafikan sekutu bagi hak Allah SWT. Sesungguhnya Allah SWT itu Ahad dan Wahid, yakni yang Maha Esa dan tiada sekutu bagi-Nya. Kalimah Ahad dan Wahid bagi hak Allah tidak boleh difahami secara literal bahawa Allah SWT itu satu dari sudut bilangan nombor. Wahid atau satu dari sudut bilangan, tetap akan menerima pecahan kerana nombor ialah susunan. Sebagai contoh, satu jika dibahagikan kepada 4 bahagian, maka ia akan menjadi $1 / 4$ kepada 4 pecahan, begitu juga seterusnya. Sedangkan Allah bukanlah satu dari sudut bilangan, dan zat Allah tidak menerima pecahan. Ini dikuatkan dengan kenyataan Imam Abu Hanifah dalam kenyataannya (Nu'man bin Thabit 1999):

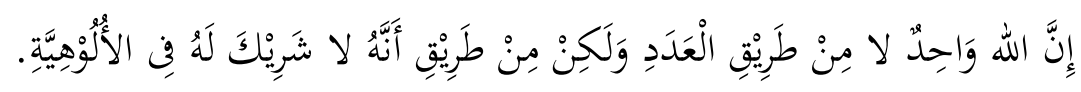

Sesungguhnya Allah itu Wahid bukan dari sudut bilangan, namun Dia Wahid dari sudut menafikan syirik bagi-Nya pada ketuhanan.

Setiap yang berbilang itu ialah jisim. Jisim menurut ulama Tauhid ialah apa yang tersusun daripada dua Jawhar atau lebih. Jawhar ini secara kefahaman yang mudahnya ialah sel, sekiranya ia berada secara tunggal maka disebut sebagai Jawhar al-Fard, manakala sekiranya ia bersusun secara gabungan, maka ia dikenali sebagai jisim. Menurut Imam Ahmad b. Hanbal, jisim ditakrifkan seperti berikut (al-Tamimi n.d.):

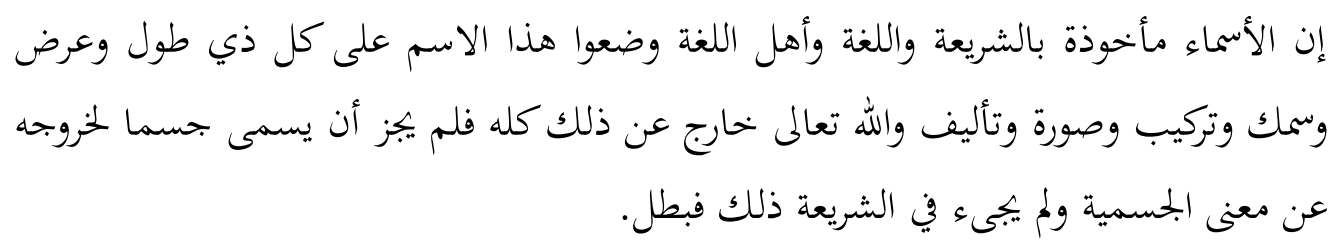

Sesungguhnya, nama-nama Allah diambil dari syariat dan dari bahasa. Adapun ahli bahasa (Arab) meletakkan nama tersebut (yakni jisim) dengan makna setiap 
sesuatu yang mempunyai ukuran ketinggian, ukuran lebar, tersusun dengan beberapa anggota, mempunyai bentuk dan sebagainya, sedangkan Allah SWT Maha Suci dari yang demikian (tidak mempunyai anggota dan sebagainya) Maka, tidak boleh menamakan Allah SWT dengan jisim kerana Allah SWT Maha Suci dari makna kejisiman (tidak beranggota, tiada ukuran, tiada bentuk dan sebagainya) dan syariat tidak menyebutnya, maka batallah faham Tajsim atau Allah SWT berjisim.

Pengingkaran bahawa Allah SWT itu berjisim merupakan Ijmak Ulama sebagaimana dinyatakan oleh Syeikh Mahmud Khattab al-Subki (1974) dalam kitabnya Ithaf al-Kainat dan Imam Mulla 'Ali al-Qari (2001) dalam Mirqat al-Mafatih Syarhi Misykaat al-Masabih. Anggota badan melazimkan jisim bagi hak Allah SWT, demikian Maha Suci Allah dari berjisim (al-Harari 2004). Ini kerana setiap sesuatu yang berjisim itu berhajat kepada yang mengkhususkannya dengan suatu ciri kepadanya seperti ukuran, saiz dan warna bagi-Nya. Yang mengkhususkan jisim-jisim ini dengan ciri yang demikian ialah Allah SWT. Sekiranya dikatakan Allah SWT itu jisim, sudah tentu ada yang mengkhususkan Allah SWT dengan suatu ukuran, saiz dan warna bagi-Nya, dan ini adalah mustahil kerana, sesuatu yang dikhususkan itu adalah lemah, yang lemah itu tidak layak menjadi Tuhan. Maha suci Allah SWT dari bersifat dengan kelemahan. Konsep tauhid inilah yang menjadi teras pegangan umat Islam. Ia berteraskan kepada konsep Tanzīh iaitu menyucikan Allah daripada sebarang persamaan dengan makhluk-Nya, baik daripada segi zatNya, sifat-Nya mahupun $a f^{c} \bar{a} l$-Nya. Daripada konsep ini lahirnya natijah iktiqad yang bersih daripada sebarang bentuk Tasybih dan Tajsim.

Selain menafikan bahawa Allah SWT itu menyerupai sesuatu yang baharu yakni makhluk, umat Islam turut berpegang dengan keyakinan yang teguh bahawa Allah SWT itu Maha Kaya yang tidak berhajat kepada makhluk-Nya. Allah SWT merupakan pencipta sekalian alam, Allah SWT tidak berhajat kepada alam ciptaan-Nya. Allah SWT bersifat dengan Azali yakni tiada permulaan, tiada sesuatupun yang wujud bersama-sama dengan Allah SWT sebagaimana ditegaskan oleh Saidina Ali r.a (al-Baghdadi n.d.):

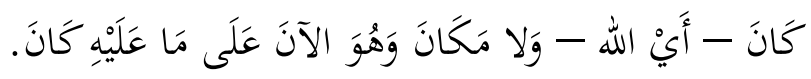

Maksudnya: Allah telah sedia ada tanpa tempat dan kita sekarang menghukumkan bahawa Dia tetap sedia ada tanpa tempat

Tempat, arah yang enam (atas, bawah, kiri, kanan, depan dan belakang), Arasy, Kursiy, langit, bumi dan sekaliannya merupakan ciptaan Allah SWT. Sebelum Allah SWT menciptakan tempat, Allah SWT telah sedia ada tanpa tempat, setelah Allah SWT menciptakan tempat, Allah SWT tidak berubah daripada tanpa tempat kepada bertempat, Allah SWT tetap sedia ada tanpa tempat. Ini kerana perubahan adalah mustahil bagi hak Allah SWT. Setiap yang berubah berhajat kepada yang mengubahnya daripada suatu keadaan kepada suatu keadaan yang lain. Contohnya manusia, manusia berubah dari bayi sehingga dewasa, yang mengubah manusia daripada usia bayi kepada usia dewasa adalah Allah SWT. Demikian, Allah SWT tidak berubah kerana perubahan berhajat kepada suatu kuasa yang mengubahnya dari suatu keadaan kepada keadaan yang lain, sekiranya Allah SWT berubah, nescaya Allah SWT itu lemah. Ini sesuai dengan perkataan Imam al-Syafie (al-Zabidi n.d.):

$$
\text { لايبجوز عليه التغيير. }
$$

Maksudnya: Tidak harus bagi Allah SWT mengalami perubahan 
Keyakinan seperti yang dinyatakan secara ringkas ini merupakan paksi kepada akidah pegangan umat Islam. Bermula dari menafikan ketuhanan selain Allah SWT dalam kalimah syahadah yang pertama, diikuti mensucikan Allah dari menyerupai makhluk-Nya dan kemudian mengimani bahawa Allah SWT terkaya dari berhajat kepada makhluk-Nya. Jika dibahas secara tafsil, maka keyakinan ini telah dimetodologikan dalam perbahasan Sifat 13 dan Sifat 20 bagi aliran Asya'irah dan Sifat 14 bagi aliran Maturidiyyah. Ia diperincikan dalam pelbagai kitab karangan ulama aliran masing-masing. Kedua aliran ini masyhur dengan gelaran Ahli Sunnah wal Jamaah (ASWJ) sebagaimana dinyatakan oleh Imam Murtadha al-Zabidi (al-Zabidi n.d.):

Apabila disebut Ahli Sunnah wal Jama'ah, maka maksudnya ialah golongan pengikut Imam Abu al-Hasan al-Asya'ari dan Imam Abu Mansur al-Maturidi

Perkara yang sama disebut oleh Ibn Abidin (Ibn Abidin 2003):

$$
\text { أهل السنة والجماعة هم الاشاعرة والماتريدية. }
$$

Maksudnya: Ahli Sunnah wal Jama'ah, mereka ialah al-Asya'irah dan alMaturidiyah

Dasarnya, akidah ketuhanan umat Islam berpegang kepada prinsip-prinsip keesaan Allah SWT dengan ciri berikut:

1. Tanzih, iaitu mensucikan Allah SWT dari menyerupai makhluk-Nya;

2. Mengimani bahawa Alah tidak berhajat kepada makhluk-Nya seperti tempat, ruang dan arah; dan

3. Mengimani bahawa Allah SWT tidak bersifat dengan sifat kelemahan seperti berubah, beranggota dan sebagainya.

Lahir daripada ciri-ciri ini, serta merujuk kepada Al-Quran, maka para ulama mengisbatkan 13 sifat bagi hak Allah SWT yang wajib diimani sekalian Muslim, diulang-ulang sifat-sifat ini dalam Al-Quran secara lafaz mahupun makna (al-Harari 2004). Sifat-sifat itu ialah:

1. Al-Wujud: Ertinya Allah SWT wujud dan tiada keraguan bagi kewujudan-Nya.

2. Al-Wahdaniyyah: Ertinya Allah SWT itu Maha Esa tidak berbilang.

3. Al-Qidam: Ertinya Allah SWT itu tiada permulaan bagi kewujudan-Nya. Wujud-Nya sedia ada, tiada didahului oleh ketiadaan.

4. Al-Baqa': Ertinya Allah SWT Maha Kekal dan tidak binasa.

5. Qiyamuhu bi Nafsihi: Ertinya Allah SWT tidak berhajat kepada makhluk-Nya seperti tempat dan masa, adapun makhluk yang berhajat kepada Allah SWT.

6. Al-Qudrah: Ertinya Allah SWT Maha Berkuasa menciptakan sesuatu daripada tiada kepada ada.

7. Al-Iradah: Ertinya Allah SWT Maha Berkehendak dengan kehendak yang azali. Kehendak Allah SWT tidak berubah. Setiap yang Allah SWT kehendaki pasti akan berlaku.

8. Al-'Ilmu: Ertinya Allah SWT Maha Mengetahui dengan ilmu-Nya yang azali, Dia mengetahui apa yang telah berlaku, sedang berlaku, akan berlaku dan apa yang akan berlaku sekiranya yang tidak berlaku itu berlaku. Ilmu-Nya tidak bertambah dan berkurang.

9. Al-Sam'u: Ertinya Allah SWT Maha Mendengar semua bunyi, baik sekecil-kecil bunyi mahupun sebesar-besar bunyi.

10. Al-Basar: Ertinya Allah SWT Maha Melihat semua perkara baik yang tersembunyi mahupun yang nyata. 
11. Al-Hayah: Ertinya Allah SWT Maha Hidup dengan kehidupan yang azali, tidak berhajat kepada darah, tulang, daging dan roh.

12. Al-Kalam: Ertinya Allah SWT Maha Berfirman dengan firman yang azali, bukan huruf, suara dan bahasa, tiada terhenti, tiada mula dan akhir.

\section{Kontroversi Terhadap Nama Brahma dan Nama Tuhan Selain Islam Sebagai Ganti Nama Bagi Allah}

Terdapat beberapa tokoh yang diangkat sebagai agamawan tetapi hakikatnya tidak mempunyai manhaj yang jelas dalam akidah mereka sehingga membenarkan penggunaan nama-nama selain Allah sebagai merujuk kepada Allah SWT. Di antara yang menimbulkan isu ini dengan sangat jelas adalah Dr. Zakir Naik dan Syeikh Nazim al-Qubrusi yang mendakwa bahawa nama selain Allah SWT boleh dirujuk kepada Allah SWT itu sendiri. Dr. Zakir Naik menerusi satu kenyataannya dalam laman sesawang (https://www.islam101.com/religions/hinduism/conceptofGod.htm 30 Sept 2018) di bawah tajuk Concept of God in Hinduism menyatakan bahawa (Zakir Naik 2018):

Among the various attributes of God, one of the beautiful attributes mentioned in the Rigveda Book II hymn 1 verse 3, is Brahma. Brahma means 'The Creator'. Translated into Arabic it means Khaaliq. Muslims can have no objection if Almighty God is referred to as Khaaliq or 'Creator' or Brahma. However if it is said that Brahma is Almighty God who has four heads with each head having a crown, Muslims take strong exception to it....Another beautiful attribute of God mentioned in the Rigveda Book II hymn 1 verse 3 is Vishnu. Vishnu means "The Sustainer'. Translated into Arabic it means Rabb. Again, Muslims can have no objection if Almighty God is referred to as Rabb or 'Sustainer' or Vishnu. But the popular image of 9[Atharveda Samhita vol 2 William Dwight Whitney page 910], Vishnu among Hindus, is that of a God who has four arms, with one of the right arms holding the Chakra, i.e. a discus and one of the left arms holding a 'conch shell', or riding a bird or reclining on a snake couch. Muslims can never accept any image of God....

Kenyataan oleh beliau ini menimbulkan kontroversi di kalangan umat Islam terutamanya dari kalangan ilmuwan di benua India. Beliau telah menamakan Brahma iaitu tuhan agama Hindu sebagai rujukan bagi Allah SWT sebagaimana yang terdapat dalam Veda. Ahli Kesatuan Ulama India dan Lembaga Mashayikh India pernah menyatakan bantahan terbuka terhadap Dr. Zakir Naik. Tidak ketinggalan beberapa imam masjid utama di India yang berpegang teguh dengan ajaran Ahli Sunnah wal Jama'ah menyatakan bahawa Dr. Zakir Naik mengelirukan dan membawa perpecahan di kalangan umat Islam terutamanya di India (Rizvi 2016).

Selain daripada Dr. Zakir Naik yang telah menamakan Brahma sebagai Allah SWT, Syeikh Nazim al-Qubrusi yang juga tokoh kontroversi dalam Tarekat Naqshabandiyyah juga pernah mendakwa bahawa sesiapa sahaja yang menyebut God atau apa-apa sahaja nama dalam bahasa masing-masing mereka adalah dianggap sebagai beriman. Jika nama tuhan tersebut adalah Yahweh seperti Yahudi, God seperti Kristian dan Brahma seperti Hindu maka mereka adalah dianggap beriman. Beliau menyatakan (al-Qubrusi 1980):

Our Grandsheikh says whoever is never saying ALLAH is a kafir, unbeliever. Anyone saying ALLAH, even in his own language, you must not say to him 'Kafir'. This is clear, our Grandsheikh is leaving this so wide, so open, not making conditions, all Prophets just came to make people, believing in their Lord, not in themselves. Anyone saying 'God' must be considered a believer. Even if a person says, as we do in English 'Oh my God', Allah is catching him. 
Para ulama sebagai mana yang telah dijelaskan sebelum ini telah mengharamkan sebarang bentuk nama yang tidak diambil secara tawqifi untuk disandarkan sebagai nama Allah SWT. Kontroversi yang dibawa oleh dua orang ilmuan yang diangkat sebagai tokoh agama ini perlu diperbetulkan agar tidak memberi kekeliruan kepada masyarakat yang masih lagi tidak benar-benar mendalami Islam. Kesannya boleh menimbulkan syak wasangka terhadap Allah SWT serta membuka jalan kepada Liberalisme yang mengancam akidah umat Islam hari ini.

Ketegasan ilmuwan-ilmuwan ini ada asasnya yang kukuh, terutama terhadap kenyataan Dr. Zakir Naik dan al-Qubrusi bahawa Umat Islam tidak keberatan (diperbolehkan) kalau Allah SWT dipanggil dengan Brahma dan Vishnu serta nama-nama yang terdapat dalam agama lain. Kenyataan ini jelas terkeluar dari asas akidah umat Islam. Sekiranya diteliti, asas kenyataan oleh Dr. Zakir Naik ialah berdasarkan Kitab Veda yang merupakan asas kepada akidah ketuhanan umat Hindu yang menyatakan mengenai ciri-ciri Brahma. Antara ciri-ciri yang dinyatakan itu sedikit sebanyak menyerupai sifat-sifat Allah SWT yang diimani umat Islam. Bagaimanapun, konklusi yang dibuat oleh Dr. Zakir Naik bahawa adalah tidak keberatan bagi umat Islam menamakan Allah SWT dengan Brahma kerana adanya ciri Brahma pada Allah SWT adalah suatu kenyataan yang salah disisi Ahli Sunah Waljamaah. Manakala pendapat al-Qubrusi mengenai sebutan 'Oh My God' memadai diperakukan sebagai beriman adalah kenyataan yang tidak tepat dan boleh mengelirukan umat Islam serta menepati dengan idea Pluralisme yang menyamakan semua tuhan dengan Allah SWT.

\section{Akidah Ketuhanan Umat Hindu}

Perlu diperjelaskan kenapa tidak boleh dinamakan Allah SWT dengan nama tuhan bagi agama lain. Hal ini kerana hakikat sama ada Zat, Sifat dan Perbuatan Allah SWT adalah amat berbeza dengan hakikat bagi tuhan-tuhan yang namanya seperti Brahma Yahweh dan God yang lain. Pada bahagian ini hanya difokuskan penjelasan mengenai mengapa tidak boleh menamakan Allah SWT dengan nama tuhan umat Hindu sahaja kerana hanya tuhan ini sahaja yang disebut oleh Zakir Naik yang dikatakan sama hakikatnya dengan Allah SWT. Manakala Syeikh Nazim al-Qubrusi tidak mengkhususkan pada mana-mana nama yang lain, maka tidak diperincikan nama selain tuhan Hindu lebih lanjut.

Berlainan dengan konsep ketuhanan umat Islam, konsep Tuhan umat Hindu adalah berteraskan kepada kitab agama Hindu yang berasaskan dua mazhab utama agama Hindu iaitu Saivisme dan Vainavisme. Penganut Hindu mempercayai banyak Tuhan. Bagi mereka setiap kekuatan alam semula jadi sama ada mendatangkan faedah atau membahayakan adalah Tuhan yang diharapkan pertolongan. Ketika dilanda kesusahan, penganut Hindu menyeru sembahansembahan ini supaya memberkati keturunan, harta benda dan menolong mereka untuk menentang musuh. Sebenarnya penyembahan kepada kekuatan tabii ini tidak dijalankan secarasekali gus tetapi berperingkat-peringkat.

Pada mulanya bentuk-bentuk alam yang indah dan menarik perhatian menimbulkan kesedaran beragama pada mereka. Mereka kagum pada bentuk-bentuk ini dan terus menikmatinya. Selepas itu mereka bersyukur dan senang dengannya, mereka memuji-muji, kemudian menyangka bahawa bentuk-bentuk ini mempunyai roh. Roh-roh ini dianggap mempunyai kekuatan yang tersembunyi di sebalik bentuk yang kelihatan lalu mendekatinya melalui perbuatan ibadat. Mereka menghadiahkan korban-korban dan menganggapnya sebagai Tuhan yang diseru ketika ada hajat. Oleh sebab itulah bilangan sembahan bertambah banyak dalam kalangan mereka. Apabila mereka menyembah salah satunya, upacara korban akan dilakukan (Azilah 2016).

Secara dasarnya, umat Hindu berpegang dengan konsep Polytheism iaitu kepercayan terhadap berbilang Tuhan. Mereka menamakan sembahan-sembahan mereka ini sebagai Brahma, Vishnu dan Siva atau juga dipanggil tiga dalam satu dan satu dalam tiga. Di bawah pemerintahan tiga sembahan ini, ada yang memerintah dan diperintah, ada ketua dan 
sebahagiannya diketuai. Ketua dan yang memerintah menjadi tuhan segala tuhan dan dewa segala dewa. Semua makhluk dan tuhan ini berada di bawah perintahnya. (Othman Bakar 2015).

Di antara ketiga sembahan ini, yang diangkat oleh penganut Hindu sebagai Tuhan paling agung ialah Brahma atau Sakuna Brahman yang juga disebut Sakara Brahman. Sifat-sifat unggul seperti Yang Maha Kuasa, yang Maha Tahu, yang Maha Besar, yang Maha Kasih dan sebagainya adalah antara sifat-sifat yang diberikan kepada Sakuna Brahman oleh penganut agama Hindu. Menurut Singaravelu, ketuhanan Brahma banyak diterjemahkan dengan simbol-simbol dalam tradisi agama Hindu seperti penyembahan patung, gambar dan lakaran dewa-dewi, simbol binatang, tumbuhan, senjata, struktur kuil dan sebagainya (Sachithanantham 2006).

Bagaimanapun, sebahagian pengkaji menganggap bahawa kepercayaan terhadap ketua Tuhan iaitu Brahma ialah suatu kepercayaan Monotheisme. Sebagai contoh Kitab Veda menyebutkan mengenai ketunggalan (Sachithanantham 2006) yang berbunyi:

\section{Om tat sat Ekam eva advityam Brahman.}

Ertinya Tuhan hanya satu, tidak ada duanya. Petikan ini secara tegas menyebutkan hanya ada satu Tuhan. Orang arif di kalangan Hindu menyebutkan bahawa bagi Tuhan ini banyak nama, sebutan Tuhan itu banyak sesuai dengan tugas dan fungsi beliau. Seperti contoh seseorang yang memiliki jawatan lebih dari satu, ketika berada di sekolah mereka akan dipanggil guru, bila mereka sedang bertani di sawah mereka akan dipanggil petani, kemudian ketika mereka menangkap ikan di laut mereka akan dipanggil nelayan. Melihat profesion orang tersebut, panggilannya menjadi lebih dari satu nama sedangkan mereka itu hanya satu orang. Demikian pula keberadaan Tuhan di sisi penganut Hindu, pada saat Dia menciptakan dunia ini beserta isinya Dia disebut Brahma, pada saat Dia memelihara disebut Vishnu, dan pada saat Dia menghancurkan ciptaan-Nya, Dia disebut Siva dan seterusnya.

Ini ditambah lagi dengan ciri-ciri yang dibahaskan oleh mereka di dalam Veda bahawa konsep Ketuhanan dalam agama Hindu ialah Brahma itu bersifat tunggal memiliki lapan sifat yang disebut dengan Asta Aiswarya (Ida Made Sugita 2014), umat Hindu mengimani sifat-sifat ini iaitu:

1. Anima: Ertinya Brahman itu Maha Kecil, lebih kecil dari partikel atom maupun neutron atau elektron yang sudah tidak lagi mempunyai sifat asal dari benda.

2. Lagima: Ertinya Brahman itu Maha Ringan, lebih ringan dari gas atau udara. Brahman dapat mengembang di udara atau di air.

3. Mahima: Ertinya Brahman itu Maha Besar, lebih besar dari alam semesta.

4. Prapti: Ertinya Brahman itu Maha Cepat, langkahnya tidak terhalang oleh apapun, boleh menjangkau semua tempat di seluruh alam. Brahman ada di mana-mana atau Wyapy Wyapaka Nirwikara.

5. Prakamya: Ertinya Brahman itu segala kehendak-Nya dapat terwujud. Manusia hanya mampu berusaha di dunia ini, akhirnya kehendak Brahman juga yang pasti jadi.

6. Isitwa: Ertinya Brahman itu Maha Mulia, kemuliaannya tiada terbanding, maka Brahman dipuja oleh seluruh dunia dengan berbagai macam nama dan cara.

7. Wasitwa: Ertinya Brahman paling berkuasa di alam semesta ini. Brahman yang menciptakan alam semesta dengan kekuatan-Nya sebagai Brahma. Brahman juga yang memelihara dan melindungi alam semesta ini dengan sebutan sebagai Dewa Vishnu. Apabila sudah masanya, Brahman juga yang akan mengembalikan alam semesta ini kepada Brahman dengan kekuatan-Nya yang disebut sebagai Dewa Siva.

8. Yatra Kama Wasayitwa: Ertinya Brahman sebagai pemegang dan pengendali kudrat atau takdir umat manusia, binatang, tumbuhan dan alam semesta. Kehendak Brahman terjadi, maka takdir Brahman sama sekali tidak boleh diubah. 


\title{
Analisis Terhadap Kenyataan Menamakan Allah Sebagai Tuhan Hindu
}

\author{
Hujah Pertama
}

Sekalian nama-nama dan sifat Allah SWT adalah Al-Husna yakni membawa makna kesempurnaan yang hakiki bagi hak Allah SWT. Allah SWT berfirman dalam Surah al-A'Raaf (7:80):

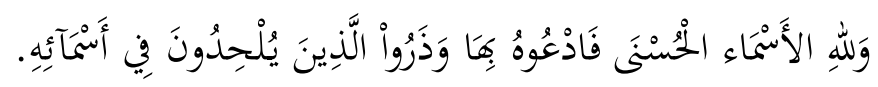

Maksudnya: Bagi Allah SWT itu nama-namayang menunjuk kesempurnaan, maka bermohonlah kepada-Nya dengan menyebut nama-nama-Nya itu dan tinggalkanlah orang-orang yang menyimpang dari kebenaran pada menamakan Allah SWT

Ulama Ahli Sunnah wal Jama'ah sepakat secara Ijma' bahawasanya nama dan sifat Allah SWT adalah bersifat Tauqifiyyah yakni, terhenti setakat apa yang dikhabarkan daripada AlQuran, Al-Sunnah dan Ijma'. Ini ditegaskan lagi dengan kenyataan Imam Abu al-Hasan al-Asya'ari (al-Isbahani n.d.):

$$
\text { لا يجوز إطلاق شيء على الله إلا ما ورد في الكتاب والسنة الصحيحة والإجماع. }
$$

Maksudnya: Haram menamakan/mensifatkan Allah SWT dengan sesuatu kecuali dari apa yang dinyatakan dalam Al-Quran, Al-Sunnah yang sahih dan Ijma'

Berdasarkan kepada kenyataan tokoh Ahli Sunnah ini, maka diketahui bahawasanya orang yang beriman tidak bermudah-mudahan dalam menamakan dan mensifatkan Allah SWT dengan suatu nama atau sifat, melainkan ianya jelas termaktub di dalam Al-Quran, Hadis yang sahih dan Ijma'. Hatta para ulama Ahli Sunnah menyebut bahawa tidak boleh menamakan Allah SWT dengan nama seperti doktor walaupun hakikatnya Allah SWT yang menyembuhkan. Begitu juga tidak boleh menamakan Allah SWT dengan faqih walaupun hakikatnya Allah SWT mengetahui hakikat setiap hukum (al-Nasafi n.d.).

Sekiranya haram menamakan Allah SWT dengan nama-nama seperti doktor atau faqih, maka apa lagi menamakan Allah SWT dengan nama berhala yang disembah oleh penganut Hindu iaitu Brahma? Maka terbatal dakwaan Dr. Zakir Naik bahawa harus memanggil Allah SWT dengan nama Brahma mahupun Vishnu berdasarkan ayat Al-Quran paling jelas bagi menghurai masalah ini, Allah SWT berfirman dalam Surah al-Syura (42:11):

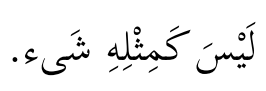

Maksudnya: Dia tidak menyerupai sesuatupun, dan sesuatupun tidak menyerupai-Nya

Di sisi umat Islam yang berpegang teguh dengan akidah Ahli Sunnah wal Jama'ah, mereka memadai berpegang dengan Hadis Nabi SAW yang menyatakan bahawa Allah SWT memiliki 99 nama yang menunjukkan kesempurnaan sebagaimana sabda Baginda SAW yang diriwayatkan oleh Imam Tirmizi r.a dalam Sunan al-Tirmizi, Juzu' 5, Hadith No. 3507 (al-Tirmizi n.d.):

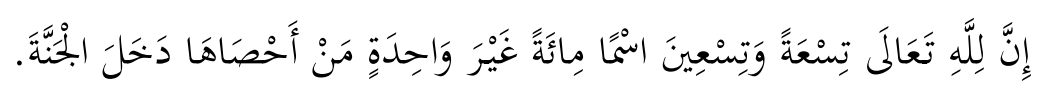


Maksudnya: Sesungguhnya bagi Allah SWT itu 99 nama, barangsiapa yang menghitungnya (hafal, faham dan mengimaninya) maka nescaya akan masuk syurga

\section{Hujah Kedua}

Menurut Dr. Zakir Naik, boleh menamakan Allah SWT dengan Brahma dan Vishnu kerana masingmasing membawa erti yang sama bagi hak Allah SWT iaitu Pencipta dan Pemelihara. Bagaimanapun menurut beliau, sekiranya dinamakan Brahma itu Allah, namun dibayangkan punya anggota badan sebagaimana diimani penganut Hindu, maka ianya tertolak.

Kenyataannya ini membawa maksud bahawa boleh menamakan Brahma namun bukan dengan Brahma yang disifati oleh umat Hindu. Menurutnya Brahma yang bukan Brahma. Ini kenyataan yang tidak tepat malah seperti bermain-main dengan bahasa sehingga membawa ketidakfahaman mengenai ketuhanan yang sebenar. Allah SWT adalah Allah SWT, manakala Brahma adalah Brahma. Walaupun terdapat beberapa ciri yang disifatkan oleh umat Hindu terhadap Brahma, seakan sama dengan sifat-sifat dan nama-nama Allah SWT yang Agung, itu tidak menjadi dalil bahawa boleh menamakan Allah SWT dengan Brahma.

Kendatipun umat Hindu beriman bahawa Brahma mereka adalah Pencipta, namun sifat Brahma yang diimani mereka itu amat berlainan dengan Allah SWT. Yang paling nyata ialah sebagaimana dinyatakan dalam Veda mengenai 8 ciri Brahma, 4 daripada ciri yang dinyatakan amat tersasar dari ketuhanan yang diyakini umat Islam iaitu Anima (Maha Kecil), Lagima (Maha Ringan), Mahima (Maha Besar) dan Prapti (Maha Cepat). Kesemua ciri yang disebut ini adalah ciri-ciri jisim yang merupakan makhluk, bukannya ciri-ciri Tuhan. Mereka meyakini Brahma lebih kecil dari atom, lebih ringan dari udara, lebih besar saiz dari alam semesta dan lebih cepat langkahnya untuk melangkaui segenap tempat.

Ciri-ciri yang disebut oleh Veda ini adalah ciri jisim, bukannya sifat Tuhan. Penegasan ini dijelaskan oleh Imam Murtadha al-Zabidi al-Hanafi (al-Zabidi n.d.):

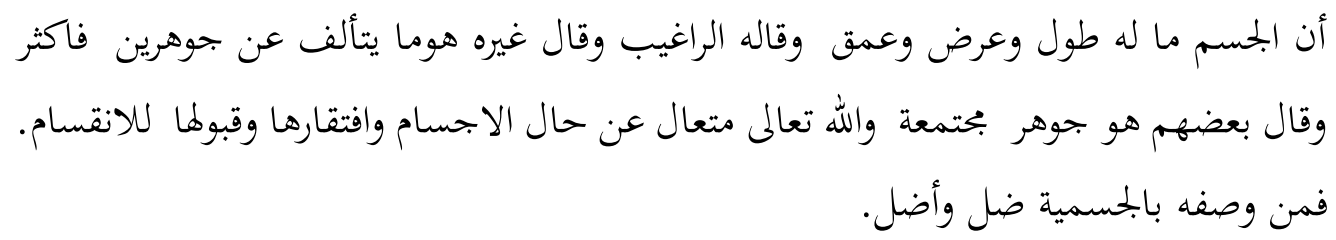

Maksudnya: Sesungguhnya jisim ialah sesuatu yang mempunyai panjang, lebar dan kedalaman, berkata al-Raghib dan selainnya: Jisim ialah sesuatu yang tersusun daripada dua jawhar (sel) atau lebih, berkata sebahagiannya yang lain: Jisim ialah jawhar yang berhimpun, dan Allah SWT Maha Suci dari perihal jisim, berhajat kepada jisim, mahupun menerima pembahagian sebagaimana jisim, barangsiapa mensifatkan Allah SWT dengan jisim maka dia nyata sesat dan menyesatkan

Berdasarkan perkataan yang dinukilkan oleh al-Zabidi ini, maka jelas bahawa Allah SWT bukan jisim yang mempunyai saiz besar atau kecil, ukuran panjang atau lebar, berat atau ringan, cepat atau lambat kerana semua ciri-ciri ini adalah jisim. Adapun bagi sebahagian nama Allah SWT seperti Akbar, ianya tidak difahami dengan erti kata saiz besar, namun ia membawa erti keagungan Allah SWT yang tiada tara-Nya. Maka terbatal dakwaan bahawa Allah SWT boleh dipanggil dengan nama Brahma, kerana Allah SWT bukan Brahma dan Brahma bukan Allah. Brahma tidak lain tidak bukan ialah sembahan umat Hindu yang jauh dari hakikat Allah SWT. 


\section{Hujah Ketiga}

Brahma dan Vishnu adalah dua sembahan yang berbeza bagi penganut Hindu. Kedua ini adalah entiti yang berbeza. Walaupun umat Hindu yang ortodoks menyatakan bahawa mereka mengesakan Brahma, manakala Vishnu dan Siva bukanlah Tuhan yang berbeza pada hakikatnya, namun ia tetap membawa kepada pewujudan 3 entiti sembahan yang menatijahkan syirik dan menyekutukan Tuhan. Umat Islam tidak menyembah Tuhan yang berbeza. Umat Islam menyembah Tuhan yang Maha Esa yang bersifat dengan segala sifat kesempurnaan. Adapun umat Hindu menyembah pelbagai sembahan kerana lahir dari keimanan kepada Brahma seterusnya Vishnu dan Siva, akhirnya kepada segala bentuk dewa-dewi yang merupakan hasil interpratasi imaginasi dan pemikiran mereka (Sachithanantham 2006). Allah SWT berfirman dalam Surah alIkhlas (112:4):

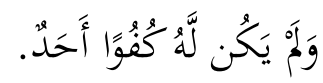

Maksudnya: Dan tiada bagi Allah SWT itu sebanding dan setara dengan-Nya.

Berdasarkan kepada kesepakatan ulama Islam, kenyataan Dr. Zakir Naik bahawa umat Islam boleh menamakan atau memanggil Allah SWT dengan panggilan Brahma adalah kenyataan yang salah dan boleh membawa kepada rosaknya akidah. Begitu juga dengan apa yang didakwa oleh Syeikh Nazim al-Qubrusi yang mendakwa bahawa sesiapa sahaja yang memanggil Allah SWT dengan nama tuhan yang lain daripada apa yang disifatkan Allah SWT secara tawqifi maka mereka adalah mukmin. Nama-nama Allah dan sifat-sifat Allah SWT adalah bersifat Tawqifiyyah, ianya bukan perkara yang boleh didasari pendapat atau ijtihad sendiri. Segala nama dan sifat Allah SWT yang dinyatakan dalam Al-Quran, Al-Sunnah dan Ijma' adalah menunjukkan kesempurnaan Allah SWT. Aqidah umat Islam tidak dapat tidak mesti selari dengan Surah alSyura (42:11) serta Surah al-Ikhlas (112:4). Adapun pendapat Zakir Naik dalam beberapa siri kenyataannya mengenai idea Brahma sebagai Allah dan pendapat Syeikh Nazim al-Qubrusi mengenai sesiapa yang menyebut "In the name of God" sudah dikira sebagai mukmin adalah pendapat yang tersasar dari manhaj akidah Ahli Sunah Waljamaah yang sebenar. Ulama bersepakat hanya apa yang dinamakan oleh Allah SWT melalui al-Quran dan Hadith sahaja yang dibenarkan untuk disandarkan kepada Allah SWT.

\section{References}

Al-Qur'an.

Abu Hanifah, Nu'man bin Tsabit. 1999. Fiqh al-Absat. al-Imarat al-Arabiyyah: Maktabah al-Furqan. Azilah, Ayu Nor. 2016. Kepercayaan kepada Tuhan: Satu Sorotan dalam Kepelbagaian Agama di Malaysia. Muzakarah Fiqh \& International Fiqh Conference 2016. Selangor: Kolej Universiti Islam Selangor, p. 128.

al-Baghdadi, Abu Mansur. n.d. al-Farq Baina al-Firaq. Beirut: Dar al-Kutub al-Ilmiyyah.

al-Harari, Abdullah. 2004. Mukhtasar Abdillah al-Harari al-Kafil bi 'Ilmi al-Din al-Dharuri. Beirut: Dar al-Mashari' li al-Taba'ati wa al-Nashri wa al-Tawzi'.

al-Harari, Abdullah. 2004. Syarh al-Qawim fi Hal Alfazh al-Sirat al-Mustaqim. Beirut: Dar alMashari' li al-Taba'ati wa al-Nashri wa al-Tawzi'.

Ibn 'Abidin, Muhammad Amin. 2003. Radd al-Mukhtar 'ala Durar al-Mukhtar (Hashiyyah Ibn 'Abidin). 14 Vols. ed. 'Adil Ahmad Abd al-Mawjud \& Ali Muhammad Mu'awwid. Riyadh: Alim al-Kutub.

Ida Made Sugita, I Ketut Widia. 2014. Pendidikan Agama Hindu dan Budi Pekerti. Jakarta: Kementerian Pendidikan dan Kebudayaan Republik Indonesia. 
al-Isbahani, Abu Bakr Muhammad bin al-Hasan bin Furak al-Shafi'i al-Ansari. n.d. Mujarrad Maqalat al-Asyaari.

Mulla Ali al-Qari al-Harwi, Nur al-Din. 2001. Mirqat al-Mafatih Sharh Mishkat al-Masabih. Tahqiq: Jamal al-Aytani. 11 Vols. Beirut: Dar al-Kutub al-Ilmiyyah.

Muslim, Mislim bin Hajjaj. n.d. Sahih Muslim. 5 Vols. Tahqiq: Muhammad Fuad Abdul Baqi. Beirut: Dar Ihya' al-Turath al-Arabi.

al-Nasafiy, Abu al-Mu'ayyan. n.d. Tabsirah al-Adillah fi Usul al-Din. Damascus: Matba'ah Al-Jafan wa Al-Jabi.

Othman Bakar, et.all. 2015. Modul Pengajian Tamadun Islam dan Tamadun Asia. Kuala Lumpur: Universiti Malaya.

al-Qubrusi, Mnazim Adil al-Haqqani. 1980. Mercy Oceans: Book Two. $1^{\text {st }}$ ed. Republic of Cyprus: The Cyprus Library.

Rizvi, Uzair Hasan. 2016. Muslim clerics in India Unite Against Superstar Televangelist Zakir Naik. Lucknow: Scroll.In.

Sachithanantham, Singaravelu. 2006. Pengajian India: BicaraPelbagai Perspektif. Kuala Lumpur: Universiti Malaya.

al-Subki, Mahmud Muhammad Khattab. 1974. Ittihaf al-Ka'inat Bi Bayan Mazhab al-Salaf Wa alKhalaf Fi al-Mutashabihat. al-Muassasah al-Ahliyyah Li al-Ajhizah al-Ilmiyyah: Maktabah al-Mahmudiyyah.

al-Tamimi, Abu al-Fadhl Abd al-Wahid bin Abd al-Aziz bin al-Harith. n.d. I'tiqad al-Imam alMunabbal Abi Abdillah Ahmad bin Hanbal. Vol. 2.

al-Tirmizi, Muhammad binj Isa bin Sawrah. n.d. al-Jami' al-Sahih Sunan al-Tirmizi. 5 Vols. Beirut: Dar Ihya' al-Turath al-Arabi.

al-Zabidi, Murtadha. n.d. Ithaaf al-Sadah al-Muttaqin Syarh Ihyaa' Ulum al-Din. Vol. 2 of 5. Beirut: Dar al-Fikr.

Zakir Naik. 2018. The Concept of God in Hinduism. Available From: https://www.islam101.com/religions/hinduism/conceptOfGod.htm. Retrieved: $\quad 30^{\text {th }}$ September 2018. 